\title{
Engineering a Woman: Marketing Opportunities and Challenges in India
}

\author{
Mahajan P. T. ${ }^{\text {, Golahit S. B. }}{ }^{2}$ \\ ${ }^{1}$ R. C. Patel Institute of Technology, Shirpur, Maharashtra, India \\ ${ }^{2}$ Department of Economics, KVPS's, S. P. D. M. College, Shirpur, Maharashtra, India \\ Email address: \\ registrar.rcpit@gmail.com (Mahajan P. T.), registrar@rcpit.ac.in (Mahajan P. T.)
}

\section{To cite this article:}

Mahajan P. T., Golahit S. B. Engineering a Woman: Marketing Opportunities and Challenges in India. American Journal of Management Science and Engineering. Vol. 2, No. 1, 2017, pp. 11-22. doi: 10.11648/j.ajmse.20170201.12

Received: February 6, 2017; Accepted: February 17, 2017; Published: March 2, 2017

\begin{abstract}
Engineering plays a key role in supporting the growth and development of a country's economy as well as in improving the quality of life for citizens. Most of developed countries witnessed economic growth with the contribution of women in engineering field. In developing countries like India women remained under-utilized resource. Women in engineering are probably the single best investment that can be made in the developing world. There is clearly room for improvement - not only in recruiting women into engineering, but also in retaining and promoting those women who wish and do enter the profession. This study was designed to investigate a perception and determination of undergraduate women towards accessing Engineering Education. The study has highlighted women's perceptions and experiences on accessing engineering education through institute's Marketing Mix strategies which enables women to take up strategic positions to enjoy success in engineering education and career. Findings of this study revealed that women students in engineering are better satisfied and act of referring services/program to others is higher than men students in terms of numbers for a particular set of marketing mix applied to gender. A qualitative research survey through a structured questionnaire for the students who are studying or have recently completed their engineering education from reputed engineering institutes affiliated to the North Maharashtra University, Jalgaon, India was conducted. The study discloses women's approach to engineering education in terms of marketing mix; program, price, place, promotion, people, physical evidence and process. Women tended to rate most the marketing criteria as having a higher level of importance than men. Women needed more communal support while making decision making of selection of engineering education. The survey is delimited to the engineering education belonging to North Maharashtra University, Jalgaon and Khandesh region, a rural part of India. Findings of the study will be useful for the institutes and direct and indirect service providers of engineering education in developing a communication program and should be utilized and integrated into all aspects of the marketing program to attract women in engineering.
\end{abstract}

Keywords: Gender, Women, Engineering Education, Selection, Marketing Services, India

\section{Introduction}

By educating a woman, we educate the whole family and directly or indirectly, we educate nation. Given that a woman has the responsibility of the whole family on herself, several studies proved that an educated woman is better capable of taking care of the health, nutrition and education of her children and family. Gender refers to the socially constructed roles, behaviors, activities and attributes that a given society considers appropriate for men and women [1]. In virtually all but a handful of countries, there are severe constraints on women's entry into higher levels of education and their work in senior professional and managerial jobs [2]. The status of women in India has been subject to many great changes over the past few millennia [3]. With a decline in their status from the ancient to medieval times, to the promotion of equal rights by many reformers, the history of women in India has been eventful [4], [5]. Women in India now participate fully in areas such as education, sports, politics, media, art and culture, service sectors, science and technology, etc. [5]. Families of engineering students provide exceptional levels of support to their children. For women in engineering, this support is crucial from the pre-college level onward. In particular, female engineers' parents tend to raise their daughters with fewer gender stereotypes and place greater 
weight on education and learning [6]. Education of girls is vital not only on grounds of social justice but also because it accelerates social transformation and human resource development of the nation. Studies have indicated that there is a strong correlation between female education and several developmental indicators such as increased economic productivity, improvement in health, increased political participation and effective investments in the next generation. There is also evidence that lower gender disparity in educational attainment for a developing country correlates with lower overall income disparity within society [7]. Negative cultural and societal attitudes, different standardsroles for boys and girls, competing demands on the girls time, economic reasons like; lack of resources, distance from college, lack of facilities for girls, lack of female teachers, lack of security both in and outside the college, curriculum not relevant and flexible, gender stereotyping in curriculum, gender unfriendly classroom environment, early marriage and child bearing, absence of women role models, fear of deterioration of social structure are the most frequently quoted stumbling blocks to female education [8]. Which leads to a very limited presence of females in higher education and the high-wage labor market. Although women are given high respect in Indian society [9], women working outside the home have been looked down upon. Reference [10], found that traditional and cultural inhibitions acquired by women from childhood, nurtured by parents, and reinforced by their socialization was the key hurdle that inhibited their urge to be in an executive or leadership position. This is further supplemented by a lack of selfdirection, independence and self-motivation to enter the male-dominated world. However, those who have reached higher echelons of organizations are seen as determined to stay, confront the barriers and secure the requisite familial support and personal drive [11]. Results of senior secondary school examinations regularly show the outstanding performance of girl students with many of them topping the merit list [12], which is a good mark for the graduation of women. As per the article published in Times of India, girls' candidates carried a tradition of surpassed boys in the Higher Secondary Certificate (HSC) examination over the last few years [13]. One notable success came in 2013, when the first two girls ever scored in the top 10 ranks of the entrance exam to the Indian Institutes of Technology (IITs) [14]. Unfortunately, due to a combination of factors including limited exposure and opportunities and lack of encouragement from role models and mentors, many qualified and talented young women do not consider a nontraditional career choice such as engineering.

\section{Women in Engineering}

Engineering plays a key role in ensuring the growth and development of a country's economy as well as in improving the quality of life for citizens within the country. There is an important link between a country's engineering capacity and its economic development [15]. Engineering is viewed in the public sphere as masculine, competitive, objective, impersonal qualities that are at odds with our images of what women are. Because engineering is a traditionally maledominated field, women may be less confident about their abilities, even when performing equally [16]. Countries like; Myanmar (65\%), Tunisia (42\%) and Honduras (41\%) lead the world in gender parity among engineers, according to latest data on female engineering graduates from the United Nations Educational, Scientific and Cultural Organization (UNESCO) [15], followed by Denmark (35\%), India (30\%) and Sweden (29\%). Women only make up $22 \%$ of engineering graduates in the UK. with Switzerland $14 \%$ and Japan 12\%. As per 2011 Censes of India, sex ratio was 943 females per 1000 male; female $48 \%$ of total population [17]. In India, reservation for women cuts across all classes and communities and is a horizontal and not vertical reservation and counts 33.33\% [18] in the state of Maharashtra and Gujrat. As per the report 2015- of All India Survey for Higher Education, out of 42.28 lakh students enrolled in Engineering and Technology, the share of female participation in this sector was relatively low; 11.84 lakh, $28 \%$ only [19]. As per the statistics available on the website of All India Council for Technical Education (AICTE dashboard), female enrollment in Engineering and Technology undergraduate program during 2012-13, 2013$15,2014-15$ and $2015-16$ was $33.83 \%, 27.77 \%, 27.71 \%$ and $28.28 \%$ respectively, which shows decline interest of women in engineering [20]. Women have contributed to the diverse fields of engineering in modern and historical times. Women are often under-represented in the fields of engineering, both in academia and in the profession of engineering. A number of organizations and programs have been created to understand and overcome this tradition of gender disparity [21]. In India, women's presence is known to range between a high of 5.8 per cent [10] to a low of roughly 3 per cent [22] of all administrative positions. They can be seen mainly in HR, IT and servicing activities.

As per the report of [23], India Hiring Intent Survey found that employment gender ratio is still at 71:29. The report further said that by providing an impactful training program to hire fresher female candidates and shape them into the high performing executives of tomorrow, the future might be completely different from today's reality' [23]. The report further emphasized that despite of number of political and industrial forums, mandated Government Policies and widespread discussion in the media, the issue of gender diversity continues to remain largely unresolved. Indeed, men's and women's jobs differ greatly, whether across sectors, industries, occupations, types of jobs, or types of firms [23]. As per the report, women constitute more than $50 \%$ of the workforce in sectors like E-commerce and Retail, however, manufacturing and engineering have less than $25 \%$ of females in their workforce, whereas, for sectors like BFSI, BFS, BPO and ITES this percentage is restricted to 25 . The report further observed gender pay gap favoring full-time working men over full-time working women with the reasons like; seniority \& work experience, salary negotiations, breaks 
in employment. Surprisingly, report noted $7 \%$ rise in employment of women compared to last year. There is good sign that the differences in employability percentage of gender is going minimum in every year passed which the report said as a good sign for India [23].

\section{Marketing Mix and Women's Access to Engineering Education}

Boys and girls differ in how they are involved in education and choice processes, illustrating changing forms of young people's gendered identities and subjectivity [24]. There has also been research focusing on gender differences in decision-making processes [25]. Reference [26] found evidence to suggest that the attributes important in determining self-esteem for women and men are different. Due to biological factors, women and men show different behaviors in terms of mood, personality or natural inclination for some skills [27]. In the decision-making process, women tend to rely on emotion that can be presented by harmony, affiliation, and betterment of self and others [28]. Marketing mix is a set of controllable marketing tools that an Institutes uses to produce the responses it wants from its various target markets [29]. Reference [29] \& [30] had discussed 7P approach to satisfy the needs of the service provider's customers: product (program), price, place, promotion, people, physical facilities and processes are discussed below.

\subsection{Program (Product)}

When it comes to educational offers, Kotler firstly refers to curricula and services [30]. Technical educational program like engineering, pharmacy etc. are the products/services of the technical educational institutes. The program and curriculum must be appropriately developed and adapted to meet the needs of the students [29]. Brooks proposes that a career must be perceived as both attainable and attractive before a woman will be motivated to choose it [31]. In adapting Vroom's (1964) [32] expectancy model of motivation to women's career choices, Brooks first describes three components of expectancy: career self-efficacy, perceived structure of opportunity and perceived social support. It is not only the course content which discourages women from doing engineering but also the selection criteria which is used to screen prospective students [33].

Men prefer practical, physical or managerial occupations while women prefer supportive, clerical, and socially oriented occupations [34]. Reference [35] hypothesized that women at the college age perceive nontraditional fields to be incompatible with having a family. Indeed, women in nontraditional programs (like engineering) expect more difficulties than women in traditional programs [34]. Reference [36] found that there is a lack of Pre-College Experience and Knowledge in Engineering due to the absence of engineering awareness from the K-12 curriculum. A lack of interest was a factor for women not choosing careers in engineering or science [37]. For women, having highly educated parents, a strong desire for control, prestige and influence and a desire for positive interaction with others are primary influencers on nontraditional occupational choice [38]. Another construct commonly used to explain women's discomfort in engineering has been "math anxiety," a profound fear of mathematics and the belief that only white men succeed in math [39]. Findings of [40] suggest that women may be more likely than men to view education as a means to influence social change and improve race relations. Reference [40] also indicated that women tend to be more satisfied than men with their college courses and instruction. In a finding of reference [41], female students appear to be slightly more interested than male students in the overall reputation of the school and its degrees and what both can do for them after graduation. Studies of engineering students have also shown that women rate their abilities lower than men, despite higher GPAs [42]. Some researchers have found that the lack of self confidence among female engineering students stems partly from their lack of technological experience and expertise, qualities deemed especially important in the engineering "culture of technical knowhow" [43].

\subsection{Price}

The price element of the services marketing mix is dominated by what is being charged for the degree or tuition fees that are required [29]. Tuition fee, fee concessions, scholarships, educational loan, cost of education, fee installments offered by the service providers (institutes) for the service delivered to the service receiver (students) includes in this category of service mix.

Because of social and economic reasons, parents may be unwilling to spend on education as well as the dowries of their daughters [8]. Parents of female students are less likely to save for college. This may be one reason why, once in school, freshman women were more likely than male freshman to report major concern about financing their education and were more likely to indicate low tuition was an important factor for them when selecting a college [44].

\subsection{Place}

Place is a measured in terms of accessibility, acceptability and convenience. This refers location of institutes $\&$ distance of institute from the targeted future students native place. The location can refer to the place where the institute is. Then, it can refer to the characteristics of the area in which the institute is located. Location can also have a relative meaning, i.e. it can be viewed in relation to where current and future students and high school students live [30].

In the rural areas, the girl child is made to perform household and agricultural chores. This is one of the many factors limiting girls' education. Physical safety of the girls, especially when they have to travel a long distance to school is the other reasons that impede girls' education [8]. Two studies, reference [45] and reference [46] have measured differences in this college selection criterion between college 
men and women, the results, college women believed location was more important as a selection criterion than college men.

\subsection{Promotion}

Promotion encompasses all the tools that institute can use to provide the market with information on its offerings: advertising, publicity, public relations and sales promotional efforts [29]. Promotion is a process of communication between an institute and service user with an aim to create a positive attitude on products and services, leading to their favoring in the process of purchase on the market [30]. As per the reference [47], most educational institutions use public relations, marketing publications and to a lesser extent, advertising. The communication is made through presentations, print \& visual advertisements, digital marketing, displays, internet \& social media [47].

Women engage in a more complex information search process than men [48]. Many studies have suggested that as a result of socialization pressures, the feminine personality emerges in terms of communion with others [49] and as a result, women see relationships as more important in their lives than men do [50]. Women appear to be more strongly motivated by affiliation needs [51] and tend to express a higher degree of interest in person-oriented professions [52]. Studies have also shown that women who enter engineering hold its extrinsic (i.e., social) value in higher regard than men do [53]. Social value is sought when individuals seek to shape the response of others [54]. For instance, when it comes to advertising on the web, males were found to have a more positive attitude than females [55]. In online purchases, word of mouth is a more influential tool for women than for men in terms of reducing perceived risk and increasing willingness [56].

\subsection{People}

People is a key instrument in educational process. Because most services are provided by the people and experienced by the people by their motivation and behavioral characteristics, they make a huge difference in customer satisfaction [57]. As per reference [58], Previous Teachers, Alumni, CurrentStudents, Parents, Siblings, Relatives, Management People and Prospective students themselves affect the decision of selection in technical education.

Career "modeling and mentoring" is essential for girls and women of all ages and races and at every developmental stage of the life span [58]. Girls in engineering perceive that they receive more parental support than their peers in any other discipline [59]. Studies have found that girls are advantaged in both non-academic areas such as parental, peer and teacher expectations and non-cognitive skills such as organization, self-discipline, attentiveness, dependability and seeking help from others [60]. Social cues can also easily discredit women and dissuade them from pursuing a degree in a field where they are underrepresented [61]. Women view their professors as advisors and role models [62] and look to them to help them understand engineering. Some have found that institutional proportionality (a large percentage of women in faculty and administrative positions) may have a greater effect on women's persistence in a major than peer group proportionality (a large percentage of female peers) [63]. An awareness of others' feelings is a trait exhibited more strongly by women than men [64]. In case of girls, parents generally take the decision regarding the academic stream to be pursued [8]. As per focus group discussions made by [40], The lack of female faculty members was discouraging to many of the young women. However, they wanted to find supportive, strong faculty advisors, regardless of gender. Parents were highly influential in students' decisions about the major, with others who influenced students were likely to be engineers or high school math or science teachers [40]. Women are more likely than men to feel that their faculty provide them with personal and professional support, thus accounting for women's greater satisfaction with faculty, curriculum, and the overall sense of community on campus [40].

\subsection{Process \& Physical Evidence}

Educational services are personal and characterized by intensive, intellectual, emotional and/or physical participation of students in a service process. Services are often realized in a number of steps, which, basically, constitute the very service process. There are numerous other processes that need to be implemented concurrently (with the finance system, accommodation, time tabling and the library) to ensure the highest level of student satisfaction [29]. Reference [65] discussed several processes and physical evidence in the form of services to be delivered which includes; Operating Services like: Infrastructure \& Technology, Faculty \& Teaching Learning Methods, Library \& Computational Facilities, Research Activities, Supporting Service like: Students Amenities \& Recreation, Campus Placements, Industry Interactions \& Tie-Ups, Co \& ExtraCurricular Activities, Safety, Security \& Medical Facilities, Gradation, Accreditation \& Recognition, Alumni Interaction, Soft Skills \& Technical Skills, Sports \& Cultural Activities, Finance \& Scholarships, and Extension Services like Campus $\&$ Social Life.

Women tend to be influenced by service quality more strongly than men [65]. At college entry, women place more value than men on the educational benefits of college, a differential that predicts women's greater interest in social activism and to their stronger commitment to promoting racial understanding [40]. In another notable study, there is evidence to suggest that women display somewhat higher levels of computer anxiety [66]. Women from social categories are the most affected by the stratification of disciplines, programs and institutions [8]. Women lag men in extracurricular engineering experiences [36]. However, boys more often engage in play activity that tends to exercise their spatial-visual skills, whereas girls tend to exercise their verbal skills [67]. As per the focus group discussions conducted by reference [36], a heavy workload, a restrictive 
curriculum, and the practice of grading on a curve were discouraging to many of the women. Who participated in social enrichment activities-were less likely to leave engineering [36]. The survey also found that Campus Life/ Climate and Policies are directly affiliated with the encouragement and satisfaction of women students. Participation in support activities is vital to women undergraduates, who need to feel that they are part of a larger caring community in engineering. Community allows students to build networks and to feel that their presence in engineering is important to others and valued. Networking can counteract the isolation that women feel-providing them with information, support, and the knowledge that they're not alone in the challenges they face [36]. The survey also found that different kinds of activities influence women's persistence differentially-those that promote social enrichment are most closely linked to women's persistence in engineering. Time is an important variable to use the Internet in which men use the Internet more frequently and for long hours while women are in the categories of moderate user [68]. Females perceived Internet as a tool of maintaining social values. There is a slight variation in the usage pattern at home between men and women due to the influence of gender role [68].

\subsection{Conceptual Framework}

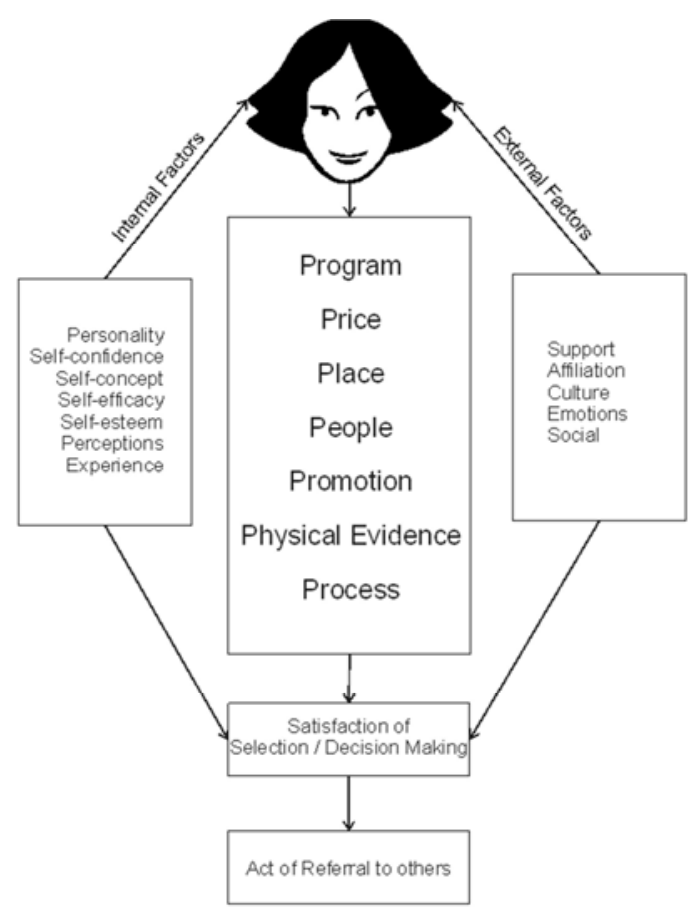

Figure 1. Women's access on marketing mix of engineering education (Own creation through literature review.).

\section{Research Methodology}

A qualitative research through a survey was made which comprised of a structured questionnaire sent through e-mail to the current-students enrolled and recently passed-out students belonging engineering education affiliated to North
Maharashtra University. Sample size (n) was calculated at 95\% Confidence Level for which Standard Normal Variate (Z) is $1.96 \&$ at Standard Error (e) of 0.03 by $n=Z^{2}$ (p) (1$\mathrm{p}) / \mathrm{e}^{2}$; where $\mathrm{n}=$ Sample Size to be used for this study, $\mathrm{N}=$ unknown population, $\mathrm{p}=$ Estimated Portion of Population $\mathrm{N}$. For $\mathrm{p}=90 \%$, ' $\mathrm{n}$ ' comes out to be 550 . Sample size of 550 was selected by quota sampling from technical institutes offering program in engineering and various students based on their location of native place and gender. The google form with questionnaire was sent through E-mail to the respondents which comprised structured and closed ended questions measuring importance, perception and experience on market mix activities of the institutes; program, price, place, promotion, people, physical evidence and process. To measure significance and impact made by marketing mix, respondents were asked to weight on a scale ranging from 0 to 5 on their perceptions / experience on the act of marketing mix. Mean of responses received gender-wise on each marketing mix activity was calculated by statistical software MiniTab 17. To measure level of satisfaction respondents were asked to weight on a scale ranging from 0 to 5 , on question 'Are you satisfied with your decision to take admission in this Institute/College?' Value zero is low weightage and value five is high weightage. To find out the act of referral the respondents were asked 'Will you refer your college to other students for admissions?'. The responses obtained were 'yes' or 'no' type. The characteristics of the sample is described as below;

By Gender: Male: 361; Female: 189

By Native Place: District: 131; Taluka: 243; Village: 176

\section{Data Interpretation and Observations}

\subsection{Women's Perception on Program}

To find out women's perception on program, gender-wise mean of responses on the importance of program, their perception on benefits of program, reason for joining the program and age of institute i.e. age of program offered by the institute were obtained and are presented in figure 2.

\begin{tabular}{|c|c|c|c|c|c|c|}
\hline \multicolumn{2}{|c|}{ Program } & & & & & \\
\hline & & & & Gender & St. Dev & Mean \\
\hline \multicolumn{7}{|c|}{1 Importance of Program } \\
\hline & & & & Female & 0.89 & 令 4.22 \\
\hline & & & & Male & 1.03 & $\checkmark 4.08$ \\
\hline \multicolumn{7}{|c|}{2 Age of Institute/Program } \\
\hline & & & & Female & 1.69 & 个 3.1 \\
\hline & & & & Male & 1.67 & $\sqrt{3}$ \\
\hline \multirow{2}{*}{\multicolumn{7}{|c|}{3 Reasons for joining Program }} \\
\hline & & & & & & \\
\hline \multirow{3}{*}{\multicolumn{2}{|c|}{ A }} & Job Prospectus and & Career & & & \\
\hline & & & & Female & 1.6 & 令 3.54 \\
\hline & & & & Male & 1.55 & $\sqrt{3.45}$ \\
\hline \multirow{3}{*}{\multicolumn{2}{|c|}{ B }} & Better quality of life & & & & \\
\hline & & & & Female & 1.55 & 舟 3.58 \\
\hline & & & & Male & 1.57 & 3.56 \\
\hline \multirow{3}{*}{\multicolumn{2}{|c|}{$\mathrm{C}$}} & Talent \& Strength & & & & \\
\hline & & & & Female & 1.57 & $\sqrt{ } 3.46$ \\
\hline & & & & Male & 1.54 & 命 3.47 \\
\hline \multirow{4}{*}{\multicolumn{2}{|c|}{ D }} & Entrepreneurship & & & & \\
\hline & & & & Female & 1.73 & $\sqrt{ } 2.45$ \\
\hline & & & & Male & 1.67 & 令 2.9 \\
\hline & & & & & & \\
\hline
\end{tabular}

Figure 2. Perception on program. 
Women students (mean=4.22) have perceived more importance of engineering program than men students. Women weighted high on the age of institute i.e age of program. Women considers Job Prospectus (mean=3.54), Better quality of life (mean=3.58) are the main benefits that they perceived by joining the engineering program. On the other hand, women thought they have marginally less talent and strength than the men students. Women (mean=2.45) are less interested in the entrepreneurship than men (mean=2.9).

\subsection{Women's Perception on Place}

To find out women's perception on place, gender-wise mean of responses on weightage given by the gender on distance of engineering institute from their native place while selecting an engineering institute were obtained and are presented in figure 3 .

\begin{tabular}{|l|l|l|l|l|l|}
\hline Place & & & & & \\
\hline \hline & & & Gender & St. Dev & Mean \\
\hline & & & & \\
\hline \multicolumn{2}{|c|}{ Distance from Native Place } & Female & 1.82 & ॠ 2.8 \\
\hline & & & Male & 1.86 & $\sqrt{2.62}$ \\
\hline & & & & & \\
\hline
\end{tabular}

Figure 3. Perception on place.

Women students (mean=2.8) have perceived more importance for a place/location of institute while selecting an engineering institute than men students (mean=2.62).

\subsection{Women's Perception on Price}

\begin{tabular}{l|c|c|c|}
\hline Price & & & \\
\hline \hline & Gender & St. Dev & Mean \\
\hline Cost of Education & & & \\
\hline & Female & 1.77 & \% 2.66 \\
\hline & Male & 1.83 & 42.51 \\
\hline
\end{tabular}

Figure 4. Perception on price.

To find out women's perception on price, gender-wise mean of responses on weightage given by the gender on cost of engineering education while selecting an engineering institute were obtained and are presented in figure 3 . Women students $($ mean $=2.66)$ have perceived more importance for cost of education while selecting an engineering institute than men students $($ mean=2.51).

\subsection{Women's Perception on People}

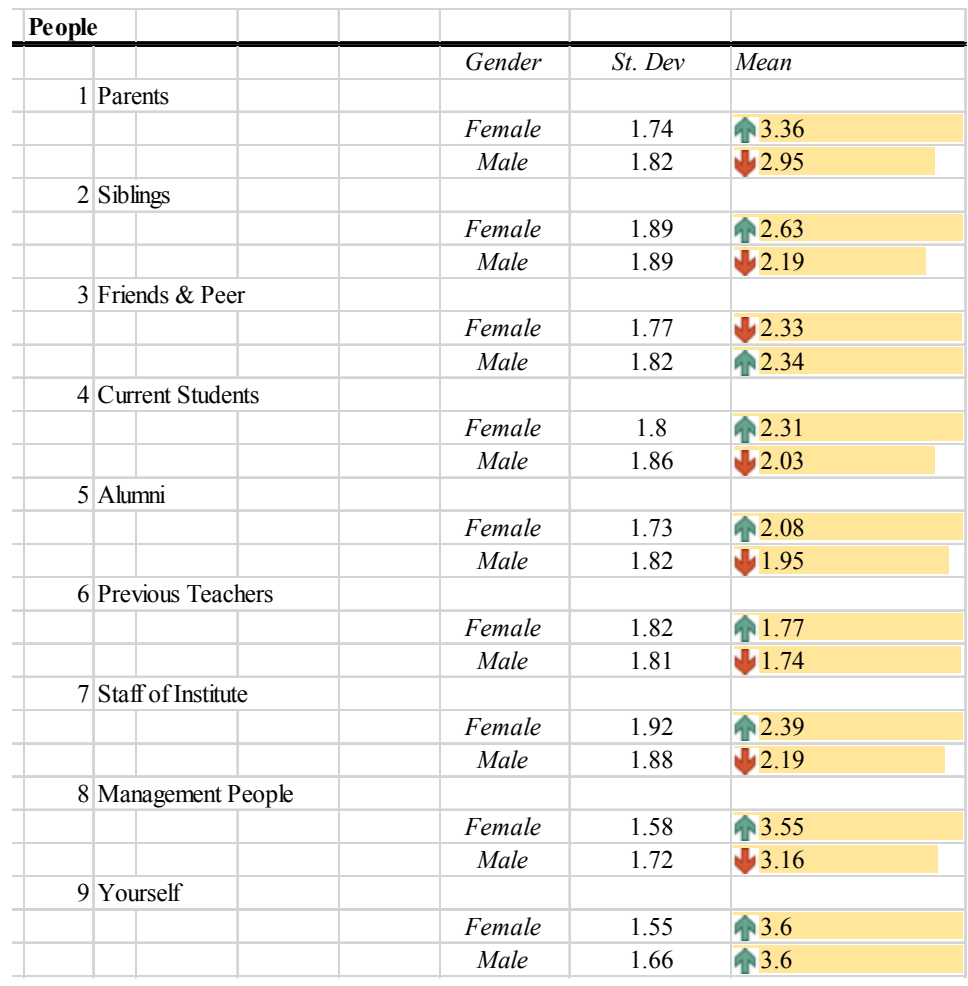

Figure 5. Perception on people. 
Women students have taken support from all possible people resources while selecting an engineering institute. Their decision of selection is mostly supported by Parents (mean=3.36), Management People (mean=3.55) and Women themselves $($ mean=3.6).

\subsection{Women's Perception on Promotion}

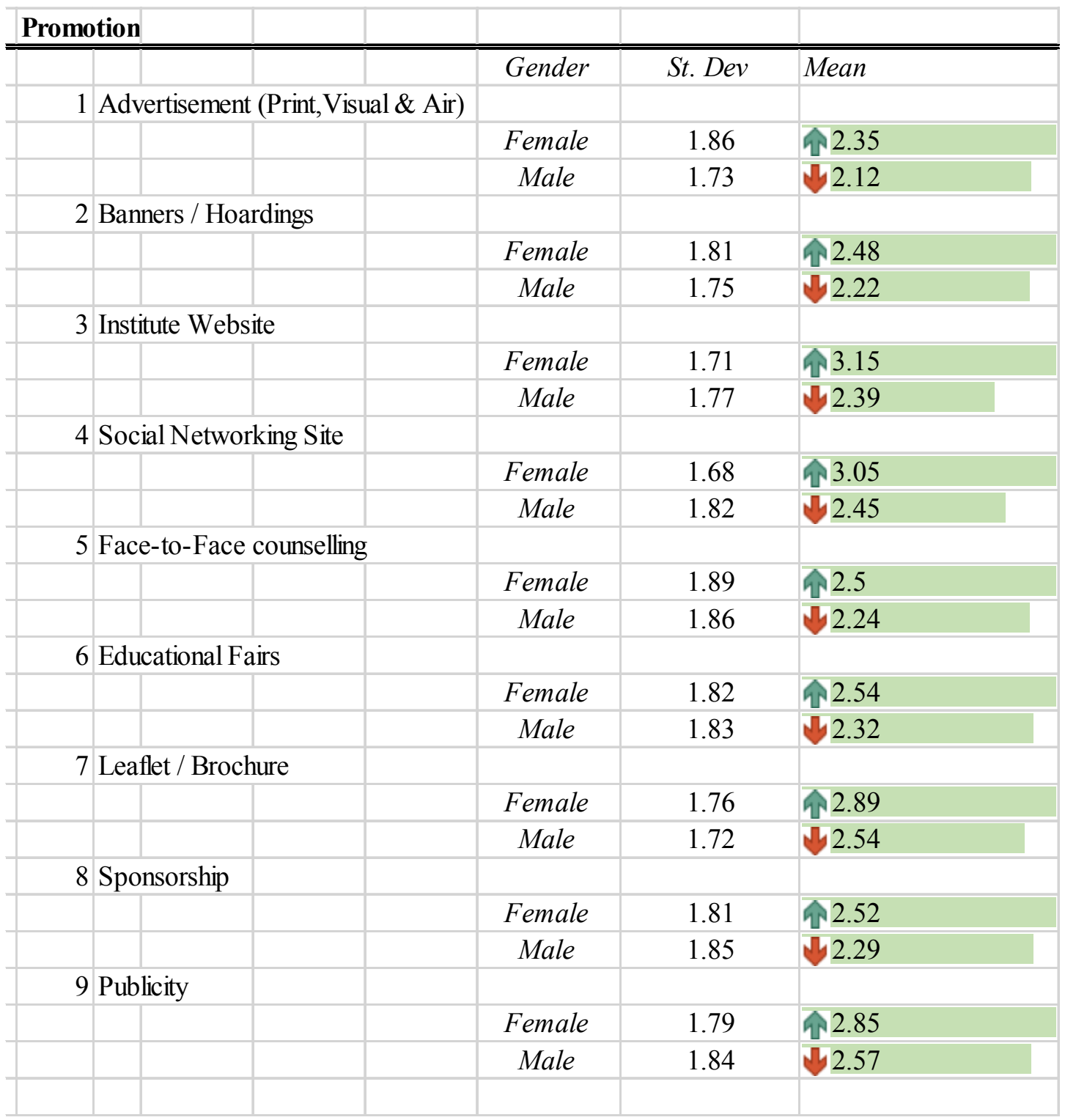

Figure 6. Perception on promotion.

Like the 'people' marketing mix, women students have collected information from all sources of institute's promotional activities. They perceived all such activities are important in making their decision of selecting engineering institute. Their selection is mostly supported by Social Networking Site (mean=3.05), Institute Website (mean=3.15), Leaflet / Brochures (mean=2.89) and Publicity (mean=2.85).

\subsection{Women's Perception and Experience on Process and Physical Evidence}

To find out women's perception and experience on process and physical evidence i.e services offered by the institute in which they are enrolled in or studied, gender-wise mean of responses on infrastructural facilities, operating services, supporting services and extension services of the institutes were obtained and their perceptions and experiences are presented in figure 7. 


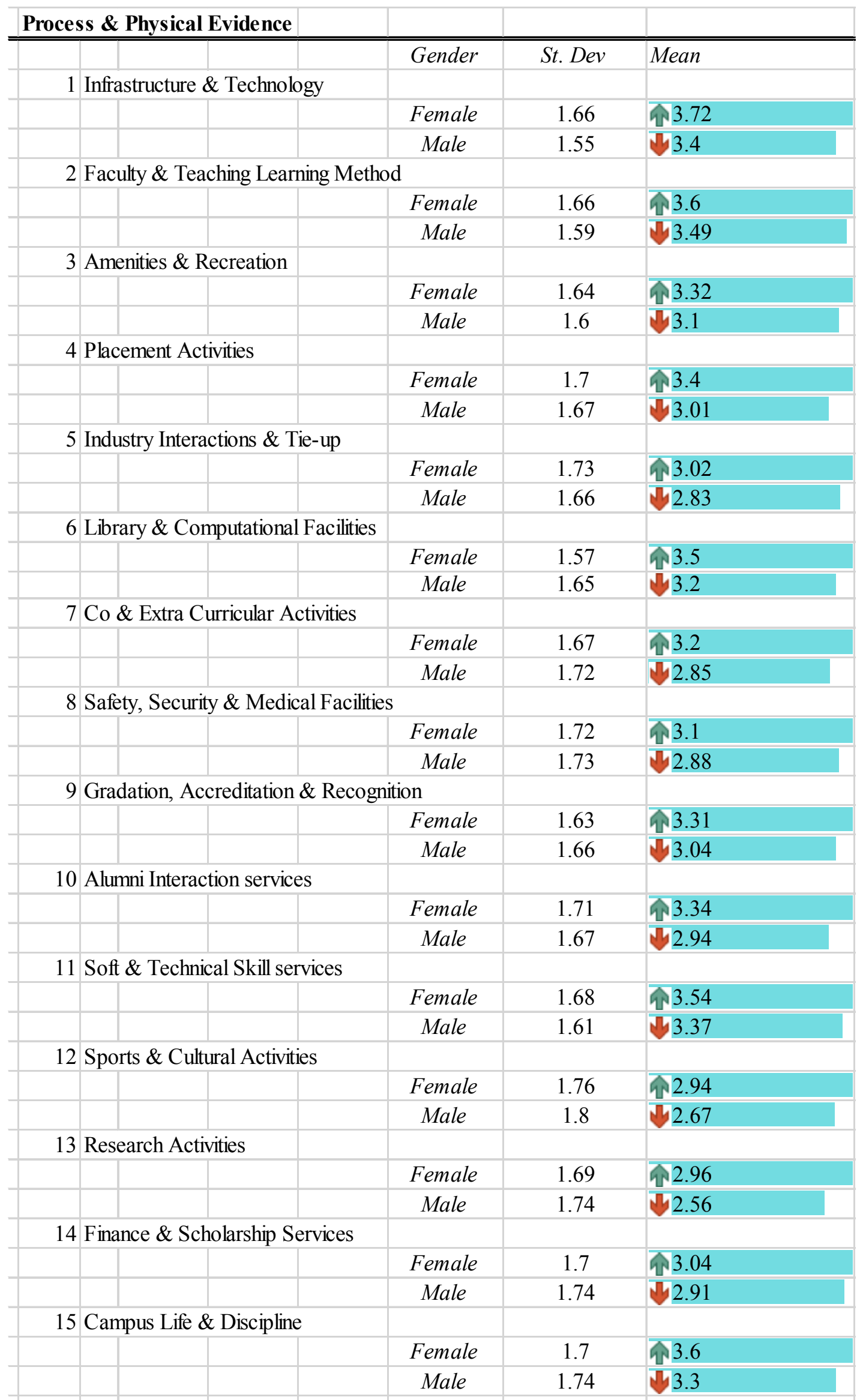

Figure 7. Perception on process and physical evidence. 
Women students have weighted more, on the services of institute experienced by them than men students. They believed that Infrastructure and Technology (mean=3.72), Faculty and Teaching Methodology (mean=3.6), Campus Life and Discipline (mean=3.6), Soft and Technical Shill service (mean=3.54), Library and Computational Facilities (mean=3.5), Placement Activities (mean=3.4), Alumni Interaction Program (mean=3.34), Accreditation, recognition and Affiliation (mean=3.31) and Amenities and Recreation $($ mean=3.32) are the better facilities and services of institutes offered to them. On the other hand, Institutes are lagging in services like Sports and Cultural activities (mean=2.94) and
Research Activities (mean=2.94).

\subsection{Women's Satisfaction on the Decision of Selection of Engineering Institute and Act of Referral to Others for Admission}

Gender-wise responses collected from the sample of 550 students on their satisfaction of decision of selection of engineering institute and their act of referring others for the engineering admission in an institute where they graduated or doing engineering are presented in Table $1 \& 2$ respectively.

Table 1. Gender-wise satisfaction on the decision of selection.

\begin{tabular}{lllll}
\hline Gender & Completely Satisfied & Some-what Satisfied & Some-what Dis-satisfied & Completely Dis-satisfied \\
\hline Female & $133(70.4 \%)$ & $45(23.8 \%)$ & $10(5.3 \%)$ & $1(0.5 \%)$ \\
Male & $173(47.92 \%)$ & $154(42.66 \%)$ & $27(7.47 \%)$ & $7(1.95 \%)$ \\
\hline
\end{tabular}

Table 2. Gender-wise responses on the act of referring others for admission.

\begin{tabular}{llll}
\hline Gender & Will prefer for admission & Can't say & Will not prefer for admission \\
\hline Female & $169(89.41 \%)$ & $15(7.94 \%)$ & $5(2.65 \%)$ \\
Male & $230(63.71 \%)$ & $116(32.14 \%)$ & $15(4.15 \%)$ \\
\hline
\end{tabular}

The research study revealed that for the same input of marketing mix activities of an engineering institute, $70.4 \%$ of women students are completely satisfied while $47.92 \%$ men students are completely satisfied. Also, dis-satisfaction level for the same marketing activities is higher $(7.47+1.95=9.42 \%)$ for male students than women students $(5.3+0.5=5.8 \%) .89 .41 \%$ of female will refer others for the admission while $63.71 \%$ of male students have shown their desire of referring their institute to others for admission.

\section{Empirical Findings and Discussions}

Challenges and Opportunities of marketing: This research study finds that females tended to rate the majority of the criteria as having a higher level of importance than did males while accessing marketing mix strategies of engineering institutes. Practitioners should be aware that males and females look for differing levels of detail.

While accessing engineering marketing mix; program, place, price, promotion and people, women have rated high importance which indicates broader, intense and integrated marketing approach is needed to attract women. On the other hand, for the same strategies provided to gender, women perceived and experienced better services provided by institutes than men students for the services; physical evidence and process.

In terms of satisfaction, women are completely satisfied (70.4\%) on their decision of selection of engineering institute than male students $(47.92 \%)$ which is greater by $46.9 \%$ in terms of numbers, for the same marketing approaches. This shows, if one male student is satisfied, 1.47 women students will be satisfied for the same marketing approach. Similarly, $89.41 \%$ women students and $63.71 \%$ male students will refer others for the admission to their respective engineering institute, which is greater by $40.34 \%$ in terms of numbers. If one male student act as a referral then, 1.40 women student will refer others for admission on the same marketing services of institute.

\section{The Road Map to Women's Inclusivity to Engineering}

Understanding the facts that women do have a more diverse set of responsibilities and often need to wear multiple hats should not compromise their chances of success or progress in any of the worlds in which they operate, the transformation process for gender inclusivity requires mapping the journey. Below is the proposal of what this will look like:

Table 3. Marketing Mix Strategies for Women's inclusivity to Engineering

\begin{tabular}{lll}
\hline Phase 1 - Pre-Student Life (School Education) & Phase 2 - Student Life (Engineering Education) & Phase 3 - Post-Student Life (On Job) \\
\hline $\begin{array}{l}\text { Marketing Mix } \\
\text { (Program, Place, People, Promotion) }\end{array}$ & $\begin{array}{l}\text { Marketing Mix } \\
\text { (Program, Price, Place, People, Promotion, Process }\end{array}$ & $\begin{array}{l}\text { Marketing Mix } \\
\text { (Process, People, Place, Promotion) }\end{array}$ \\
- Knowledge, Awareness & \& Physical Evidence) & \\
- And creating importance & $\bullet$ Gendered infrastructure, amenities and services & Social connectivity, Memberships \\
- Involving Role Models & $\bullet$ Retention and building confidence & $\bullet$ Flexible work schedule or Time concession \\
- Career Counselling & $\bullet$ Engaging women staff with women students & $\bullet$ Safe and secured transportation and \\
\hline
\end{tabular}




\begin{tabular}{lll}
\hline Phase 1 - Pre-Student Life (School Education) & Phase 2 - Student Life (Engineering Education) & Phase 3 - Post-Student Life (On Job) \\
\hline & & residence nearby work location. \\
- Family and social support & - Financial support, fee concession and & - Awards and Rewards \\
- Proposals/Offers & scholarships & - Adequate Reservation \\
- Equal treatments & - Safe and secured residential facility & - Grievance Management and lawful policies \\
- Active Participation & - Social activities & - Ensure gender mix in top management \\
- Self-actualization & - Special coaching classes and training & - Cross cultural exposure \\
- Family, Schools, Society, Government & - Adequate Reservation & \\
\hline
\end{tabular}

An ideal state in a process of inclusion is one where minorities are totally empowered. In this case, it means that women are empowered to make choices in all spheres of life and that the same opportunities available to anyone else (especially men) are available to them. This is different from saying they are equal, for it is time to move away from the original claim of the equality movement and towards one that recognizes differences and tailors responses relevant to those differences. The success of this roadmap is dependent on increased levels of awareness, acceptance and partnership from both sexes, the government and the society. Therefore, at many levels and in many ways, both men and women need to recalibrate their roles and expectations for this to happen.

\section{Conclusion}

Equity does not just mean an equal number of women and men; it means equal chances of success and career development; average women will succeed as much as average men. The Indian governments initiatives like National Program for Education of Girls at Elementary Level (NPEGEL), Rashtriya Mahilakosh (RMK), Kasturba Gandhi Balika Vidyalaya (KGBV), Working Women Hostels, National Mission for Empowerment of Women (NMEW), Sarva Shiksha Abhiyan shall be extended and oriented further more towards engineering education for the dream come true of Digital India and Smart Cities with more encouragement of women in engineering. The strategic marketing aim must be to 'normalize' engineering as a career choice for women, so that people inside and outside of engineering no longer presume that 'the engineer' will be men. Marketing efforts to recruit more women into engineering must avoid appealing to gender which associate men and masculinity with 'things technical' and women with 'things social'. In sum, we must broaden the image and vision of engineering work from technical to techno-social if we are to attract and keep talented women in engineering. Engineering has room for diverse 'types' of people because it incorporates a wide variety of jobs and roles. Women engineering education is a multi-dimensional phenomenon; marketing efforts to attract women in engineering shall not be limited to the institutes/service providers, but it shall be responsibility of the government, NGOs and community as a whole, for India to be Super Power. If engineering education is a signifier of development, it should incorporate a gender perspective to it. Perhaps then, we will see more women enjoying success and fully participating in engineering education.

\section{References}

[1] World Health Organization (2002). "Gender and Reproductive Rights: Working Definitions". Retrieved 15 November 2012.

[2] ELSON, D. (2000) Progress of the World's Women 2000. UNIFEM Biennial Report (New York, UN Development Fund for Women).

[3] The Hindu. "Rajya Sabha passes Women's Reservation Bill". Chennai, India: 10th March 2010. Retrieved 25 August 2010.

[4] Jayapalan (2001). Indian society and social institutions. Atlantic Publishers \& Distri. p. 145. ISBN 978-81-7156-925-0.

[5] National Resource Center for Women. "Women in History". Archived from the original on 2009-06-19. Retrieved 24 December 2006.

[6] Assessing Women in Engineering (AWE) Project 2005. Family Influence. AWE Research Overviews. https://www.engr.psu.edu/awe/misc/ARPs/Family_03_17_05. pdf.

[7] Hanushek, Eric. "Schooling, Gender Equity, and Economic Outcomes." In Girls' education in the 21 st century: gender equality, empowerment, and economic growth. Washington DC: World Bank, 2008. 23-40.

[8] Singh, Nandita. "Higher Education for Women in India-Choices and Challenges." Forum on Public Policy Online. Vol. 2007. No. 1. Oxford Round Table. 406 West Florida Avenue, Urbana, IL 61801, 2007.

[9] Budhwar, P. (2001) Doing business in India, Thunderbird International Business Review, 43(4), pp. 549-568.

[10] Kulkarni, S. S. (2002) Women and professional competency a survey report, Indian Journal of Training and Development, XXXII(2), April-June, pp. 11-16.

[11] Nath, G. (2000) Gently shattering the glass ceiling: experiences of Indian women managers, Women in Management Review, 15(1), pp. 44-52.

[12] PAWAN S. BUDHWAR, DEBI S. SAINI \& JYOTSNA BHATNAGAR (2011). Women in Management in the New Economic Environment: The Case of India. Asia Pacific Business Review. Vol. 11, No. 2, 179-193.

[13] Ganjapure, Vaibhav (2008). Women on top in HSC Results. Times of India. $\mathrm{http}: / /$ timesofindia.indiatimes.com/city/nagpur/Women-ontop-in-HSC-results/articleshow/3110351.cms. 
[14] Times of India. "In a first, girls among IIT entrance test toppers - Times Of India".

Articles.timesofindia.indiatimes.com. 2013-06-22. Retrieved 2013-10-06.

[15] Royal Academy of Engineering (2016). Engineering and economic growth: a global view. A report by Centre for Economics and Business Research for the Royal Academy of Engineering. London. September 2016.

[16] Jones, Brett D.; Ruff, Chloe; Paretti, Marie C. (2013). "The impact of engineering identification and stereotypes on undergraduate women's achievement and persistence in engineering". Social Psychology of Education An International Journal.

[17] Census of India. "Population" (PDF). Government of India (2011).

[18] DNA. "Gujarat increases women's reservation to $33 \%$ in government jobs". dna. 14 October 2014. Retrieved 2015-0903 .

[19] Ministry of Human Resource Development, All India Survey on Higher Education (AISHE).

http://aishe.gov.in/aishe/reports. AISHE 2014-15, p-3, 13-14.

[20] All India Council for technical Education (AICTE, New Delhi); http://www.aicte-

india.org/dashboard/pages/graphs.php.

[21] wikipedia.com. Women in Engineering. https://en.wikipedia.org/wiki/Women_in_engineering.

[22] Singh, K. (2003) Women managers: perception vs. performance analysis, Journal of Management Research, 3(1), pp. 31-42.

[23] India Skill Report - 2017: https://wheebox.com/india-skillsreport-2017.htm. p:22-24.

[24] MIRIAM E. DAVID, STEPHEN J. BALL, JACKIE DAVIES \& DIANE REAY (2003). Gender Issues in Parental Involvement in Student Choices of Higher Education. Gender And Education Vol. 15, Iss. 1, 2003.

[25] Crow, S. M., Fok, L. Y., Hartman, S. J., \& Payne, D. M. (1991). Gender and values: What is the impact on decision making? Sex Roles, 25, 255-268.

[26] Tashakkori, A. (1993). Gender, ethnicity, and the structure of self-esteem: An attitude theory approach. Journal of Social Psychology, 133, 479-488.

[27] Saucier, D. M., \& Elias, L. J. (2001). Lateral and sex differences in manual gesture during conversation. Laterality, 6(3), 239-245.

[28] Meyers-Levy, J. (1988). Influence of sex roles on judgment. Journal of Consumer Research, 14(4), 522-530.

[29] Ivy, Jonathan. "A new higher education marketing mix: the 7Ps for MBA marketing." International Journal of educational management 22.4 (2008): 288-299.

[30] Gajić, Jelena. "Importance of marketing mix in higher education institutions." Singidunum Journal of Applied Sciences 9.1 (2012): 29-41.

[31] Brooks, L. (1988). Encouraging women's motivations for nontraditional career and lifestyle options: A model for assessment and intervention. Journal of Career Development,
$14,223-241$.

[32] Vroom, V. H. (1964). Work and motivation. New York: Wiley.

[33] Sharon Beder, 'Towards a More Representative Engineering Education', International Journal of Applied Engineering Education, vol. 5, no. 2, 1989, pp173182.

[34] Chatterjee, J., \& McCarrey, M. (1989). Sex role attitudes of self and those inferred of peers, performance, and career opportunities as reported by women in nontraditional vs. traditional training programs. Sex Roles 21, 653-669.

[35] Morgan, D. L. (1988). Focus Groups as Qualitative Research. Newbury Park: SAGE Publications.

[36] Goodman, I. F., Cunningham, C. M., Lachapelle, C., Thompson, M., Bittinger, K., Brennan, R. T., \& Delci, M. (2002). A comprehensive evaluation of women in engineering programs. Goodman Research Group, Inc.

[37] Dick, T. P., \& Rallis, S. F. (1991). Factors and influences on high school students' career choices. Journal for Research in Mathematics Education 22(4), 281-292.

[38] Ware, N. C., Steckler, N. A. \& Leserman, J. (1985). Undergraduate women: Who chooses a science major? Journal of Higher Education 56 (1), 73-84.

[39] Tobias, S. (2000). Ideology of recruitment of women in science and math. Paper presented at the National Symposium on the Advancement of Women in Science, Harvard University, Cambridge, MA.

[40] Sax, Linda and Harper, Casandra (2007). Origins of the Gender Gap: Pre-College and College Influences on Differences Between Men and Women. Research in Higher Education 48(6):669-694 September 2007.

[41] Phylis M. Mansfield \& Jacquelyn Warwick (2006) Gender Differences in Students' and Parents' Evaluative Criteria When Selecting a College, Journal of Marketing for Higher Education, 15:2, 47-80.

[42] Jackson, L. A., Gardner, P. D., \& Sullivan, L. A. (1993). Engineering persistence: past, present, and future factors and gender differences. Higher Education, 26(2), 227-246.

[43] Mcllwee, J. S., \& Robinson, J. G. (1992). Women in engineering: Gender, power, and workplace culture. Albany, NY: State University of New York Press.

[44] Jacobs, J. (1999). "Gender and the Stratification of Colleges," The Journal of Higher Education, 70/2 (March/April), pp. 161-187.

[45] Shank, M. and Beasley, F. (1998). "Gender Effects on the University Selection Process," Journal of Marketing for Higher Education, 8 (3), 63-71.

[46] Hayes, T., Walker, H., and Trebbi, G. (1995). "Promoting to Women: It's Not What You Think," in Proceedings for the Symposium for the Marketing of Higher Education. Chicago, IL: American Marketing Association.

[47] Kotler, P., Fox, K. (1995) Strategic Marketing for Educational Institutions. New Jersey: Prentice-Hall.

[48] Richard, M., Chebat, J., Yang, Z., \& Laroche, M. (2007). Selective versus Comprehensive Processors: Gender Differences in Web Consumer Behavior. Advances in Consumer Research - NA Conference Proceedings, 34, 303303. 
[49] Chodorow, N. (1974). Family structure and feminine personality. InM. Z. Rosaldo and L. Lamphere (Eds.), Women, culture, and society. Palo Alto: Stanford Univ. Press.

[50] Hodgson, R. C., \& Watson, E. D. (1987). Gender-integrated management teams. Business Quarterly, 52, 68-72.

[51] Hoffman, L. W. (1972). Early childhood experiences and women's achievement motives. Journal of Social Issues, 28, $129-155$.

[52] Weller, L., Shlomi, A., \& Zimont, G. (1976). Birth order, sex, and occupational interest. Journal of Vocational Behavior, 8, $45-50$.

[53] Frehill, L. M. (1997). Education and occupational sex segregation: The decision to major in engineering. The Sociological Quarterly, 38(2), 225-249.

[54] Holbrook, M. B. (2006). Consumption experience, customer value, and subjective personal introspection: An illustrative photographic essay. Journal of Business Research, 59, 714 725.

[55] Seock, Y., \& Bailey, L. (2008). The Influence of College Students' Shopping Orientations and Gender Differences on Online Information Searches and Purchase Behaviours. International Journal of Consumer Studies, 32, 113121.

[56] Garbarino, E., \& Strahlievitz, M. (2004). Gender differences in the perceived risk of buying online and the effects of receiving a site recommendation. Journal of Business Research, 57, 768-775.

[57] Pike \& Kuh (2005). First and second-generation college students: A comparison of their engagement and intellectual development. The Journal of Higher Education. 76(3).

[58] McDaniels, C., \& Gysbers, N. C. (1992). Counseling for Career Development. San Francisco, CA: Jossey-Bass.

[59] Mahajan, P., Golahit, S. (2017). Encouraging Enrolments by People's Influence; A desperate need for Technical Education Evolution. International Journal of Engineering Trends and Technology (IJETT) - Volume-43 Number-3 -January 2017. p:130-137.

[60] Ciccocioppo, A.-L., Stewin, L. L., Madill, H. M., Montgomerie, T. C., Tovell, D. R., Armour, M.-A., \& Fitzimmons, G. W. (2002). Transitional Patterns of Adolescent Females in Non-traditional Career Paths. Canadian Journal of Counseling, 36(1), 25-37.
[61] Dylan Conger and Mark C Long (2013). Women students dominating in many countries. University World News. Issue No:26.

1http://www.universityworldnews.com/article.php?story=2013 022612105131 .

[62] Zeldin, A. L., \& Pajares, F. (2000). Against the odds: Selfefficacy beliefs of women in mathematical, scientific, and technological careers. American Educational Research Journal, 37(1), 215-246.

[63] Seymour, E., \& Hewitt, N. M. (1994). Talking about leaving: Factors contributing to high attrition rates among science, mathematics, and engineering undergraduate majors: Final report to the Alfred P. Sloan Foundation on the ethnographic inquiry at seven institutions.: University of Colorado: Ethnography and Assessment Research, Bureau of Sociological Research.

[64] Sax, L. J. (1996). The dynamics of 'tokenism': How college students are affected by the proportion of women in their major. Research in Higher Education, 37(4), 389-425.

[65] Rosenkrantz, P., Vogel, P., Bee, H., Broverman, I., \& Broverman, D. M. (1968). Sex-role stereotypes and selfconcepts in college students. Journal of Consulting and Clinical Psychology, 32, 287-295.

[66] Heejin, L., \& Kumar, A. (2008). Gender and Loyalty in the Context of Mobile Services. International Journal of Mobile Communications, 6, 714728 .

[67] Mahajan P. T and Golahit S. B. (2017); ONLY EDUCATION IS NOT ENOUGH: A NECESSITY OF ALL-INCLUSIVE SERVICES FOR TECHNICAL EDUCATION. Int. J. of Adv. Res. 5 (1). 1246-1253] (ISSN 2320-5407). www.journalijar.com.

[68] Bozionelos, N. (1996). Psychology of computer use: XXXIX. Prevalence of computer anxiety in British managers and professionals. Psychological Reports, 78, 995-1002.

[69] Sadker, M., Sadker, D., \& Klein, S. (1991). The issue of gender in elementary and secondary education. Review of Research in Education 17, 269-333.

[70] Thanuskodi, S, "Gender Differences in Internet Usage among College Students: A Comparative Study" (2013). Library Philosophy and Practice (e-journal). Paper 1052. http://digitalcommons.unl.edu/libphilprac/1052. 